\title{
Correction to: Are evaluative cultures national or global? A cross-national study on evaluative cultures in academic recruitment processes in Europe
}

\author{
Ingvild Reymert ${ }^{1} \cdot$ Jens Jungblut ${ }^{2} \cdot$ Siri B. Borlaug ${ }^{1}$
}

Published online: 10 April 2021

(C) The Author(s) 2021

\section{Correction to: Higher Education https://doi.org/10.1007/s10734-020-00659-3}

Due to an oversight by the Publisher during typesetting stage, there was an error in respect to the name of Siri B. Borlaug. The country "Norway" was mistakenly captured as part of the first name, hence the presentation "Norwary Siri B. Borlaug". His name is now correctly presented here as well as in the original article.

Publisher's Note Springer Nature remains neutral with regard to jurisdictional claims in published maps and institutional affiliations.

The original article can be found online at https://doi.org/10.1007/s10734-020-00659-3

Ingvild Reymert

ingvild.reymert@nifu.no

1 Nordic Institute for Studies in Innovation, Research and Education (NIFU), Oslo, Norway

2 Department of Political Science, University of Oslo, Oslo, Norway 